\title{
Current practices regarding the management of infrapatellar fat pad during total knee arthroplasty: A survey of orthopedic surgeons
}

\section{Total diz artroplastisi sırasında infrapatellar yağ yastığının yönetimi ile ilgili güncel uygulamalar: Ortopedi cerrahları arasında bir anket araştırması}

\author{
Sercan CAPKIN ${ }^{1} \square$, Ramadan OZMANEVRA ${ }^{2 *} \square$, Nihat Demirhan DEMIRKIRAN ${ }^{3} \square$, Serkan GULER ${ }^{1} \square$
}

'Aksaray University, Faculty of Medicine, Department of Orthopedics and Traumatology, 68200, Aksaray, TURKEY

${ }^{2}$ University of Kyrenia, Faculty of Medicine, Department of Orthopedics and Traumatology, Kyrenia/ NORTHERN CYPRUS

${ }^{3}$ Kütahya Health Sciences University, Faculty of Medicine, Department of Orthopedics and Traumatology, 43000, Kütahya, Turkey

\begin{abstract}
Aim: The aim of this study was to evaluate the current practices pertaining to the management of the infrapatellar fat pad (IPFP) during primary total knee arthroplasty (TKA) among orthopedic surgeons in Turkey.

Material and Methods: A web-based survey of orthopedic surgeons registered in the database of the Turkish Orthopedics and Traumatology Association was conducted between June 2020 and July 2020. The survey questionnaire consisted of seven questions pertaining to the current practices regarding management of the IPFP (preservation of IPFP, partial resection, or total resection) during primary TKA.
\end{abstract}

Results: Of the 1553 registered orthopedic specialists, 266 (17\%) completed the questionnaire. A vast majority of orthopedic surgeons $(75.2 \%)$ claimed that their decision making with regard to the management of IPFP during TKA was not based on evidence $(p<0.001)$.

Conclusion: In a vast majority of respondents, the decision to resect or preserve the IPFP during TKA was not based on scientific reasons. The number of years of experience in the profession and academic position had a significant influence on this decision.

Keywords: Fat pad ; orthopedics; orthopedic surgeon; total knee arthroplasty

Corresponding Author*: Ramadan Ozmanevra, University of Kyrenia, Faculty of Medicine, Department of Orthopedics and Traumatology, Kyrenia/ NORTHERN CYPRUS

E-mail:rozmanevra@gmail.com

ORCID: 0000-0003-0515-4001

Recevied: 13.01.2021 accepted: 02.6.2021

Doi: $10.18663 /$ tjcl.859748 


\section{öz}

Amaç: Bu çalışmanın amacı Türkiye'deki ortopedi cerrahları arasında primer total diz artroplastisi (TDA) sırasında infrapatellar yağ yastığının (IPFP) yönetimine ilişkin güncel uygulamaları değerlendirmektir.

Gereç ve Yöntemler: Türkiye Ortopedi ve Travmatoloji Derneği veri tabanına kayıtlı ortopedi cerrahlarına yönelik web tabanlı bir anket Haziran 2020 ile Temmuz 2020 arasında gerçekleştirilmiştir. Anket, IPFP'nin yönetimine ilişkin mevcut uygulamalara ilişkin yedi sorudan oluşmaktadır (IPFP'nin korunması, birincil TDA sırasında kısmi rezeksiyon veya tam rezeksiyon).

Bulgular: 1553 kayıtlı ortopedi uzmanından 266'sı (\% 17) anketi tamamladı. Ortopedi cerrahlarının büyük çoğunluğu (\% $75,2)$ TDA sırasında IPFP'nin yönetimi ile ilgili karar vermelerinin kanıta dayalı olmadığını iddia etti $(p<0,001)$.

Sonuçlar: Ankete katılanların büyük çoğunluğunda, TKA sırasında IPFP'yi rezeksiyon veya koruma kararı bilimsel nedenlere dayanmıyordu. Meslek ve akademik pozisyondaki yılların sayısı bu karar üzerinde önemli bir etkiye sahipti.

Anahtar Kelimeler: Yağ yastığı; ortopedi; ortopedik cerrah; total diz artroplastisi

\section{Introduction}

Total knee arthroplasty (TKA) is the most frequently performed arthroplasty procedure. Advances in TKA have revolutionized the management of knee osteoarthritis; the reported patient satisfaction rates are as high as $90 \%$ [1]. The infrapatellar fat pad (IPFP) (also referred to as Hoffa's fat pad) is an intra-capsular structure located between the inferior pole of the patella and the proximal patellar tendon. During TKA, total or partial excision of IPFP is often performed to achieve better surgical exposure of the lateral compartment of the knee joint $[2,3]$. However, the IPFP is considered as an important anatomical structure with a rich blood supply and nerve fibers. Resection of IPFP is considered as a potential cause of postoperative anterior knee pain, patellar fractures, as well as scarring and shortening of the patellar tendon leading to patella baja [46]. The main function of IPFP and the consequences of IPFP excision are not well elucidated. The decision to preserve or resect the IPFP is mainly based on the preference of individual surgeons and the operative needs; the pros and cons of each approach are widely debated [7].

There is no clear consensus on the impact of IPFP resection on the outcomes of TKA. In addition, there are no definitive guidelines on whether to resect or preserve the IPFP during TKA. The aim of this study was to determine the current practices of orthopedic surgeons in Turkey regarding management of the IPFP in patients undergoing primary TKA; in addition we evaluated the reasons for preservation or resection of IPFP in these patients.

\section{Materials and Methods}

In this cross-sectional study, we conducted a web-based survey of members of the Turkish Orthopedics and Traumatology
Association using the organization's mailing list. The study was conducted in accordance with the principles of the Declaration of Helsinki. All orthopedic surgeons registered in the database were informed about the aims of the survey and provided a link to the online survey form (Google Forms, Google Inc.) via e-mail. The survey questionnaire contained seven questions pertaining to the current practices regarding the management of IPFP during primary TKA. There were multiple response options for each question (Appendix 1).

The professional profile of orthopedic surgeons including years of experience as a surgeon and academic position were assessed. The participants were asked about the number of primary knee arthroplasty operations performed by them in a year. Participants were asked to report whether they prefer complete resection, partial resection, or preservation of IPFP. The reasons for preservation and resection of the IPFP were enquired separately via two multiple choice questions. The participants were also asked whether their decisions are based on any evidence or guidelines.

\section{Statistical analyses}

SPSS 15.0 for Windows program was used for statistical analysis. Categorical variables are presented as frequency and percentage. Comparison of rates in independent groups was performed using Chi Squared test. P values of $<0.05$ were considered indicative of statistical significance.

\section{Results}

Out of the 1553 specialist members registered in the Turkish Orthopedics and Traumatology Association mailing list, 266 orthopedic specialists (17\%) completed the survey.

The professional profile of respondents and the number of 
TKA performed in a year are summarized in Table 1. The vast majority of respondents [200 (75.2\%)] claimed that their decision to preserve or resect the IPFP was not based on any guidelines or evidence. Out of the 266 respondents, 144 (54.1\%) resorted to partial resection of the IPFP, $74(27.8 \%)$ resorted to total resection of the IPFP, while 32 (12\%) preserved or resected the IPFP based on the individual circumstances; 16 (6\%) respondents claimed that they routinely preserved the IPFP. Question 6 assessed the reasons for preservation of IPFP. Of the 48 surgeons who preserved the IPFP either routinely or in selected cases, $49.3 \%$ cited the following reason for IPFP preservation:'resection causes complications by disrupting the circulation of patellar tendon and patella'. The detailed analysis of the responses to question 6 is summarized in Table 2.

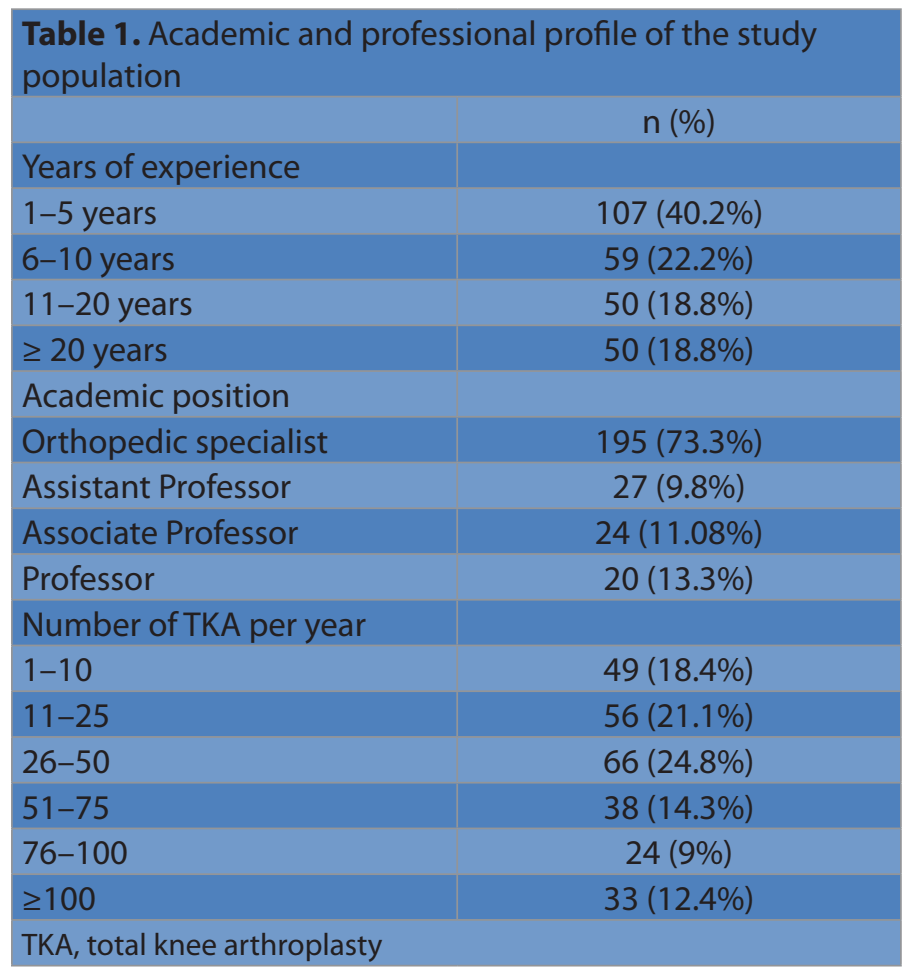

\begin{tabular}{|c|c|}
\hline Answers & $\mathrm{n}(\%)$ \\
\hline Habit (clinical experience) & $25(37.3 \%)$ \\
\hline Resection causes anterior knee pain after surgery & $27(40.3 \%)$ \\
\hline $\begin{array}{l}\text { Resection causes complications by disrupting } \\
\text { the circulation of patellar tendon and patella }\end{array}$ & $33(49.3 \%)$ \\
\hline Resection reduces the knee range of motion & $4(6 \%)$ \\
\hline $\begin{array}{l}\text { Better functional and clinical results when com- } \\
\text { pared with 'resection' }\end{array}$ & 15 (22.4\%) \\
\hline IPFP, infrapatellar fat pad & \\
\hline
\end{tabular}

Question 7 assessed the reason for partial or total resection of IPFP; $79.9 \%$ of respondents who resorted to either partial or total resection of IPFP cited 'easier access to the lateral tibial plateau and easier placement of the tibial component' as the reason. The detailed analysis of responses to question 7 is summarized in Table 3.

\begin{tabular}{lc}
\hline Table 3. Reasons cited for resection of IPFP & \\
\hline Answers & $\mathrm{n}(\%)$ \\
\hline Habit (clinical experience) & $96(39.3 \%)$ \\
\hline It facilitates mobilization of patella & $83(34 \%)$ \\
\hline $\begin{array}{l}\text { Easier access to the lateral tibial plateau and } \\
\text { easier placement of the tibial component }\end{array}$ & $195(79.9 \%)$ \\
\hline Resection increases the range of motion & $12(4.9 \%)$ \\
\hline $\begin{array}{l}\text { Better functional and clinical results when } \\
\text { compared with 'preservation' }\end{array}$ & $23(9.4 \%)$ \\
\hline IPFP, infrapatellar fat pad &
\end{tabular}

The vast majority of respondents (75.2\%) claimed that their decision-making with regard to the management of IPFP during TKA was not based on any evidence $(p<0.001)$.

We found that the experience of the respondents, their job position, or the number of TKA procedures performed per year had no significant effect on the decision making with regard to the management of the IPFP during TKA ( $p=0.460$, $p=0.975$, and $p=0.728$, respectively).

We observed a significant association between the experience of respondents and the reasons cited for partial or total resection of IPFP. A significantly higher proportion of respondents with 1-5 years or 6-10 years of experience cited the following reasons for performing partial or total resection (as compared to respondents with $11-20$ or $\geq 20$ years of experience): 'habit (clinical experience)' and 'it makes patella easier to deviate' (Table 4).

A significantly greater proportion of Associate Professors and Professors stated that they performed partial or total resection in order to achieve 'better functional and clinical results' as compared to Orthopedic specialists and Assistant Professors (Table 5). There was no significant association of experience or job position with the reasons cited for IPFP preservation $(p<0.05)$. However, the number of TKA performed in a year showed a significant association with the reason cited for IPFP preservation $(p<0.05)$. Orthopedic surgeons who performed less than 75 TKA per year stated that they resorted to IPFP preservation because resection of IPFP causes anterior knee pain after surgery (Table 6). The number of TKA performed annually also showed a significant association with the reasons cited for partial or total resection of IPFP. The proportion of respondents who cited habit or clinical experience as the reason for performing partial or total resection during TKA was lowest among those who performed 51-75 TKA annually (Table 6). 


\begin{tabular}{|c|c|c|c|c|c|c|c|c|c|c|}
\hline & & \multicolumn{9}{|c|}{ Experience } \\
\hline & & \multicolumn{2}{|c|}{$1-5$ years } & \multicolumn{2}{|c|}{$6-10$ years } & \multicolumn{2}{|c|}{$11-20$ years } & \multicolumn{2}{|c|}{$\geq 20$ years } & \multirow[b]{2}{*}{$\mathrm{p}$} \\
\hline & & $\mathrm{N}$ & $\%$ & $\mathrm{n}$ & $\%$ & $\mathrm{n}$ & $\%$ & $\mathrm{n}$ & $\%$ & \\
\hline \multirow{5}{*}{$\begin{array}{l}\text { Reason for partial or total } \\
\text { resection of the IPFP }\end{array}$} & Habit (clinical experience) & 8 & 32,0 & 3 & 21,4 & 1 & 7,7 & 3 & 20,0 & $0,003^{*}$ \\
\hline & It facilitates mobilization of patella & 53 & 52,0 & 21 & 38,2 & 11 & 25,0 & 11 & 25.6 & $<0.001^{*}$ \\
\hline & $\begin{array}{l}\text { Easier access to the lateral tibial plateau and } \\
\text { easier placement of the tibial component }\end{array}$ & 46 & 45.1 & 22 & 40.0 & 5 & 11.4 & 10 & 23.3 & 0.679 \\
\hline & Resection increases the range of motion & 83 & 81.4 & 41 & 74.5 & 35 & 79.5 & 36 & 83.7 & 0.618 \\
\hline & $\begin{array}{l}\text { Better functional and clinical results } \\
\text { when compared with 'preservation' }\end{array}$ & 6 & 5.9 & 1 & 1.8 & 2 & 4.5 & 3 & 7.0 & 0.599 \\
\hline
\end{tabular}

*Pearson's Chi squared test, Bold values indicate statistical significance. IPFP, infrapatellar fat pad

\begin{tabular}{|c|c|c|c|c|c|c|c|c|c|c|}
\hline & & \multicolumn{9}{|c|}{ Academic Position } \\
\hline & & \multicolumn{2}{|c|}{$\begin{array}{l}\text { Orthopedic } \\
\text { specialist }\end{array}$} & \multicolumn{2}{|c|}{$\begin{array}{l}\text { Assistant } \\
\text { Professor }\end{array}$} & \multicolumn{2}{|c|}{$\begin{array}{l}\text { Associate } \\
\text { Professor }\end{array}$} & \multicolumn{2}{|c|}{ Professor } & \multirow[b]{2}{*}{ 年 } \\
\hline & & $\mathrm{n}$ & $\%$ & $\mathrm{n}$ & $\%$ & $\mathrm{n}$ & $\%$ & $\mathrm{n}$ & $\%$ & \\
\hline \multirow{5}{*}{$\begin{array}{l}\text { Reason for } \\
\text { 'partial or to- } \\
\text { tal resection' } \\
\text { of the IPFP }\end{array}$} & Habit (clinical experience) & 75 & 41,2 & 11 & 45,8 & 5 & 25,0 & 5 & 27,8 & 0,331 \\
\hline & It facilitates mobilization of patella & 68 & 37,4 & 8 & 33,3 & 3 & 15,0 & 4 & 22,2 & 0,154 \\
\hline & $\begin{array}{l}\text { Easier access to the lateral tibial plateau and } \\
\text { easier placement of the tibial component }\end{array}$ & 143 & 78,6 & 21 & 87,5 & 14 & 70,0 & 17 & 94,4 & 0,199 \\
\hline & Resection increases range of motion & 10 & 5,5 & 0 & 0,0 & 1 & 5,0 & 1 & 5,6 & 0,786 \\
\hline & $\begin{array}{l}\text { Better functional and clinical results when } \\
\text { comparing to 'preservation' }\end{array}$ & 13 & 7,1 & 2 & 8,3 & 5 & 25,0 & 3 & 16,7 & $0,038^{*}$ \\
\hline
\end{tabular}

Table 6. Association between the number of TKA performed per year and the reasons cited for preservation and resection of the IPFP during TKA

Number of TKA per year

\begin{tabular}{|c|c|c|c|c|c|c|c|c|c|c|c|c|c|c|}
\hline & & \multicolumn{13}{|c|}{ Number of TKA per year } \\
\hline & & \multicolumn{2}{|c|}{$1-10$} & \multicolumn{2}{|c|}{$11-25$} & \multicolumn{2}{|c|}{$26-50$} & \multicolumn{2}{|c|}{$51-75$} & \multicolumn{2}{|c|}{$76-100$} & $\geq 100$ & \multirow[b]{2}{*}{$\%$} & \multirow[b]{2}{*}{$p$} \\
\hline & & $\mathrm{n}$ & $\%$ & $n$ & $\%$ & $\mathrm{n}$ & $\%$ & $\mathrm{n}$ & $\%$ & $\mathrm{n}$ & $\%$ & $\mathrm{n}$ & & \\
\hline \multirow{5}{*}{$\begin{array}{l}\text { Reasons } \\
\text { for pres- } \\
\text { ervation } \\
\text { of the } \\
\text { IPFP }\end{array}$} & Habit (clinical experience) & 3 & 25,0 & 1 & 11,1 & 5 & 33,3 & 5 & 55,6 & 2 & 22,2 & 9 & 69,2 & 0,057 \\
\hline & $\begin{array}{l}\text { Resection to cause anterior knee } \\
\text { pain after surgery }\end{array}$ & 8 & 66,7 & 6 & 66,7 & 4 & 26,7 & 5 & 55,6 & 2 & 22,2 & 2 & 15,4 & $0,030^{*}$ \\
\hline & $\begin{array}{l}\text { Resection to causes complications } \\
\text { by disrupting the circulation of } \\
\text { patellar tendon and patella }\end{array}$ & 4 & 33,3 & 5 & 55,6 & 11 & 73,3 & 5 & 55,6 & 4 & 44,4 & 4 & 30,8 & 0,241 \\
\hline & $\begin{array}{l}\text { Resection reduction of range of } \\
\text { motion }\end{array}$ & 0 & 0,0 & 1 & 11,1 & 1 & 6,7 & 0 & 0,0 & 0 & 0,0 & 2 & 15,4 & 0,591 \\
\hline & $\begin{array}{l}\text { Better functional and clini- } \\
\text { cal results when comparing to } \\
\text { 'resection' }\end{array}$ & 2 & 16,7 & 4 & 44,4 & 4 & 26,7 & 2 & 22,2 & 1 & 11,1 & 2 & 15,4 & 0,631 \\
\hline \multirow{5}{*}{$\begin{array}{l}\text { Rea- } \\
\text { sons for } \\
\text { partial } \\
\text { or total } \\
\text { resection } \\
\text { of the } \\
\text { IPFP }\end{array}$} & Habit (clinical experience) & 13 & 28,9 & 23 & 43,4 & 32 & 53,3 & 7 & 20,6 & 10 & 43,5 & 11 & 37,9 & $0,028^{*}$ \\
\hline & $\begin{array}{l}\text { It facilitates mobilization of } \\
\text { patella }\end{array}$ & 12 & 26,7 & 22 & 41,5 & 24 & 40,0 & 8 & 23,5 & 7 & 30,4 & 10 & 34,5 & 0,396 \\
\hline & $\begin{array}{l}\text { Easier access to the lateral tibial } \\
\text { plateau and easier placement of } \\
\text { the tibial component }\end{array}$ & 35 & 77,8 & 40 & 75,5 & 50 & 83,3 & 31 & 91,2 & 17 & 73,9 & 22 & 75,9 & 0,451 \\
\hline & $\begin{array}{l}\text { Resection increases range of } \\
\text { motion }\end{array}$ & 1 & 2,2 & 4 & 7,5 & 3 & 5,0 & 2 & 5,9 & 1 & 4,3 & 1 & 3,4 & 0,925 \\
\hline & $\begin{array}{l}\text { Better functional and clinical results } \\
\text { when comparing to 'preservation' }\end{array}$ & 3 & 6,7 & 5 & 9,4 & 7 & 11,7 & 5 & 14,7 & 2 & 8,7 & 1 & 3,4 & 0,716 \\
\hline
\end{tabular}


Appendix: Survey questions

1. How many years have you been an orthopedic specialist?

o 1-5 years

o 6-10 years

o 11-20 years

$0 \geq 20$ years

2. Which of the following best describes your current academic position?

o Orthopedic specialist

- Assistant Professor

o Associate Professor

o Professor

3. How many primary total knee arthroplasties do you perform annually?

o $1-10$

0 11-25

o $26-50$

0 51-75

0 $76-100$

$0 \geq 100$

4. Do you make the decision to preserve or resect the infrapatellar fat pad while making a total knee arthroplasty, according to any guidelines or evidence?

o Yes (I do it according to a guideline or evidence)

o No (I don't do it according to a guideline or evidence)

5. Which of the following procedures do you apply to the infrapatellar fat pad (Hoffa's fat pad) when performing a total knee arthroplasty?

o Routinely preservation (if your answer is yes, please answer the 6th question )

o Routinely partially resection (if your answer is yes, please answer 7th question )

o Routinely total resection in total (if your answer is yes, please answer the 7th question)

o Sometimes preservation and sometimes resection (if your answer is yes, please answer both the 6th and 7th questions)

6. What is the reason for you to 'preserve' the infrapatellar fat pad? (you can select multiple options)

o Habit (clinical experience)

o Resection causes anterior knee pain after surgery

o Resection causes complications by disrupting the circulation of patellar tendon and patella

o Resection reduces of range of motion

o Preservation provides better functional and clinical results when compared to resection

7. What is the reason for you to 'partially or totally resect' the infrapatellar fat pad? (you can select multiple options)

o Habit (clinical experience)

o It facilitates mobilization of patella

o Easier access to the lateral tibial plateau and easier placement of the tibial component

o Resection increases range of motion

o Resection provides better functional and clinical results when compared to preservation 


\section{Discussion}

Prior to this study, we presumed that the experience and job position would be key determinants of the decision to preserve the IPFP during TKA. However, we found no significant effect of these factors on the decision. Nonetheless, we found that the experience and job position significantly affected the decision to perform partial or total resection of IPFP. On the contrary, the reasons cited for preserving the IPFP were not affected by the experience (working years in the profession) and the job position; however, the number of TKA performed annually showed a significant correlation with the reason cited for IPFP preservation.

In particular, we observed that orthopedic surgeons working as academicians attributed their decision to preserve or resect IPFP to a scientific reason. A greater proportion of respondents with 1-10 years of experience in the profession cited habit and easier patellar deviation as the reason for performing partial or total resection; we believe that this phenomenon is attributable to the lack of definnitive guidelines. Owing to the lack of consensus in this regard and the absence of guidelines, this issue is largely unaddressed during classical specialty training. Similarly, this topic is not addressed in the courses and professional forums. However, orthopedic surgeons who continue their professional life as an academician have greater access to contemporary literature; therefore, they tend to at least advocate an evidence-based approach.

In a cadaveric study, excision of the IPFP was found to alter the patellar position, patellar tendon length, and the range of motion of knee. This ex vivo study showed that IPFP excision decreases the tibial external rotation relative to the femur, causes a significant medial translation of the patella, and reduces the retropatellar pressure [8]. Complete excision of the IPFP during TKA may cause injury to the lateral genicular artery and damage the vascular supply of patellar tendon, thus causing tendon scarring [9]. In some previous studies, excision of the IPFP was found to cause shortening of the patellar tendon, increase the incidence of anterior knee pain, and reduce the extent of flexion; however, other studies found no significant difference in terms of patellar tendon length, anterior knee pain, or range of motion when comparing IPFP excision with IPFP preservation [2, 3, 9-16]. A recent systematic review aimed to clarify the influence of IPFP resection or preservation on outcomes of primary TKA; the results of the review were inconclusive vis-à-vis the superiority of one surgical technique over the other [17]. In another similar systematic review, IPFP resection showed a trend towards a decrease in patellar tendon length as well as a higher incidence of anterior knee pain in the medium-term. However, the authors emphasized that the available evidence regarding resection or preservation of the IPFP is not conclusive [18].

The 2004 National Joint Registry report for England and Wales showed total or partial removal of IPFP in $86 \%$ of patients undergoing primary TKAs [19]. In a survey of 173 orthopedic surgeons in the UK, $9.83 \%$ of respondents preferred total preservation of the IPFP, $23.12 \%$ preferred total resection, and $62.4 \%$ favored partial resection. Furthermore, only $23 \%$ of respondents were aware of any guidelines or evidence to support their surgical decision [20].

In our study, $82 \%$ of the respondents performed total or partial resection of IPFP. These results are similar to the 2004 UK and Wales National Joint Registry report [19]. Similarly, in a survey of orthopedic surgeons in England conducted by van Duren et al. [20] ( $n=173), 9.83 \%$ of the respondents stated that they completely preserve the IPFP. In addition, only $23 \%$ of the respondents based their opinions on any guideline or evidence. In our study, $6 \%$ of respondents completely preserved the IPFP. In addition, only $24.8 \%$ respondents claimed that their opinion about preservation of IPFP was based on any scientific evidence.

\section{Conclusion}

In a vast majority of respondents, the decision-making about resection or preservation of IPFP during TKA was not based on scientific reasons. The number of years of experience in the profession and the academic position of the respondents were key determinants of this decision. We believe that continuing education of orthopedic surgeons is required to facilitate informed decision about management of IPFP. Further research on this subject will contribute to the development of definitive guidelines in future.

\section{Declaration of conflict of interest}

The authors received no financial support for the research and/or authorship of this article. There is no conflict of interest

\section{References}

1. Choi YJ, Ra HJ. Patient satisfaction after total knee arthroplasty. Knee Surg Relat Res 2016; 28: 1-15.

2. Lemon M, Packham I, Narang K, et al. Patellar tendon length after knee arthroplasty with and without preservation of the infrapatellar fat pad. J Arthroplasty 2007; 22: 574-80. 
3. Gwyn R, Kotwal RS, Holt MD, et al. Complete excision of the infrapatellar fat pad is associated with patellar tendon shortening after primary total knee arthroplasty. Eur J Orthop Surg Traumatol 2016; 26: 545-9.

4. Banks SA, Hodge WA. Implant design affects knee arthroplasty kinematics during stair-stepping. Clin Orthop Relat Res 2004; 426: 187-93.

5. Van Beeck A, Clockaerts S, Somville J, et al. Does infrapatellar fat pad resection in total knee arthroplasty impair clinicaloutcome? A systematic review. Knee 2013; 20: 226-31.

6. White L. The impact of an intact infrapatellar fat pad on outcomes after total knee arthroplasty. Adv Orthop Surg 2015; 2015.

7. Ye C, Zhang W, Wu W, et al. Influence of the infrapatellar fat pad resection during total knee arthroplasty: a systematic review and meta-analysis. PLoS One 2016; 11: e0163515.

8. Bohnsack M, Wilharm A, Hurschler C, et al. Biomechanical and kinematic influences of a total infrapatellar fat pad resection on the knee. Am J Sports Med 2004; 32: 1873-80.

9. Chougule SS, Stefanakis G, Stefan SC, et al. Effects of fat pad excision on length of the patellar tendon after total knee replacement. J Orthop 2015; 12: 197-204.

10. Maculé F, Sastre S, Lasurt S, et al. Hoffa's fat pad resection in total knee arthroplasty. Acta Orthop Belg 2005; 71: 714-17.

11. İmren $Y$, Dedeoğlu SS, Çakar M, et al. Infrapatellar fat pad excision during total knee arthroplasty did not alter the patellar tendon length: a 5-year follow-up study. J Knee Surg 2017; 30: 479-83.

12. Tanaka N, Sakahashi H, Sato E, et al. Influence of the infrapatellar fat pad resection in a synovectomy during total knee arthroplasty in patients with rheumatoid arthritis. J Arthroplasty 2003; 18: 897-902.
13. Gandhi R, de Beer J, Leone J, et al. Predictive risk factors for stiff knees in total knee arthroplasty. J Arthroplasty 2006; 21: 46-52.

14. Meneghini RM, Pierson JL, Bagsby $D$, et al. The effect of retropatellar fat pad excision on patellar tendon contracture and functional outcomes after total knee arthroplasty. J Arthroplasty 2007; 22: 47-50.

15. Pinsornsak $P$, Naratrikun $K$, Chumchuen $S$. The effect of infrapatellar fat pad excision on complications after minimally invasive TKA: a randomized controlled trial. Clin Orthop Relat Res 2014; 472: 695-701.

16. Maculé $F$, Sastre $S$, Lasurt $S$, et al. Hoffa's fat pad resection in total knee arthroplasty. Acta Orthop Belg 2005; 71: 714-17.

17. Yao B, Samuel LT, Acuña AJ, et al. Infrapatellar fat pad resection or preservation during total knee arthroplasty: a systematic review. J Knee Surg 2019.

18. Nisar S, Lamb JN, Somashekar N, et al. Preservation vs. resection of the infrapatellar fat pad during total knee arthroplasty part II: A systematic review of published evidence. Knee 2019; 26: 422-6.

19. National Joint Registry for England and Wales:: 1 st Annual Report September 2004. Available: www.njrcentre.org.uk. Accessed 6 June 2020

20. Van Duren BH, Lamb JN, Nisar S, et al. Preservation vs. resection of the infrapatellar fat pad during total knee arthroplasty Part I: a survey of current practice in the UK. Knee 2019; 26: 416-21. 